\title{
Sağlık Alanında Maliyet ile İlgili Yayımlanmış Makalelerin Bibliyomerik Analizi ${ }^{1}$
}

\author{
Dr. Öğr. Üyesi Aynur TORAMAN² - Doç. Dr. Burcu ASLANTAŞ ATEŞ³
}

Başvuru Tarihi: 05.11.2019 Kabul Tarihi: 30.11.2020Ｍakale Türü: Derleme

\section{Öz}

Bu çalışma, sağlık alanında maliyet konulu makalelerde, maliyetin en çok hangi yönünün çalışıldığını ve en fazla hangi sağlık biriminin uygulamaya konu edildiğini tespit etmek ve böylece, hangi sağllk kurumunda ve biriminde hangi konunun daha az çalışıldiğını göstererek araştırmacılara yol göstermek amacıyla gerçekleştirilmiştir. Bu amaç kapsamında çalışılmayan konuların belirlenmesi, bundan sonraki süreçte araştırma yapacak olanlara yol gösterir nitelikte olması adına da önemlidir. Bu kapsamda, DergiPark veri tabanında "hastane", "maliyet", "sağllk kurumları" ve "sağlık işletmeleri" anahtar kelimeleri kullanılarak tarama gerçekleştirilmiş ve çalışmalara ait bibliyometrik verilere ulaşılmıştır. Çalışmalar; yıllar, çalışma yapılan sağlık kurum ve birimleri, çalışma konuları ve yazar sayıları bağlamında incelenmiştir. Çalışmada nitel araştırma yöntemlerinden bibliyometrik analiz tekniği kullanılmıştır. Bibliyometrik özellikler çerçevesinde değerlendirmeye alınan toplamda 72 makale analize tabi tutulmuştur. Analizsonrasında, makale sayılarının yıllar itibariyle dağılımında 2016 yılından sonra büyük bir ivme kazandı̆̆ı tespit edilmiştir. Radyoloji birimine ait maliyet çalışmalarının diğer birimlere oranla çarpıcı bir şekilde fazla olduğu görülmüş̧ür. Sonuç olarak sağlık maliyeti konusunda Türkiye'de yapılan ve DergiPark' ta yayınlanan makalelerin mevcut durumu ortaya konulmaya çalışılmıştır. Alandaki bilgi boşluğuna, bibliyometrik analiz sayesinde ışıł tutulmuşve bundan sonra yapılacak olan çalışmalara yol göstereceği kanısına varılmıştır.

Anahtar Kelimeler: Sağlık Kurumları, Sağlıkta Maliyet, Maliyet Analizi, Bibliyometrik Analiz

Atıf: Toraman, A. ve Ateş, B. (2020). Sağlık alanında maliyet ile ilgili yayımlanmış makalelerin bibliyomerik analizi. Anadolu Universitesi Sosyal Bilimler Dergisi, 20(4), 151-162.

\footnotetext{
${ }^{1}$ Bir önceki yıl dergiye yayın başvurusunda bulunulmuş makale olduğundan geriye dönük etik kurul izni gerekmemektedir.

${ }^{2}$ Süleyman Demirel Üniversitesi İİBF, aynurtoraman@sdu.edu.tr, ORCID: 0000-0001-6180-4713

${ }^{3}$ Süleyman Demirel Üniversitesi İİBF, burcuates@sdu.edu.tr, ORCID: 0000-0002-8896-5303
} 


\title{
Cost-Related Articles in Health Care: A Bibliometric Analysis
}

\author{
Asst. Prof. Dr. Aynur TORAMAN - Assoc. Prof. Dr. Burcu ASLANTAŞ ATEŞ
}

Submitted by: 05.11.2019

Accepted by: 30.11 .2020

Article Type: Review

\begin{abstract}
This study was carried out in order to determine which aspects of the cost are the most studied and which health unit has proved to be most analyzed study in the cost-related articles in health care, and thus aiming to guide the researchers by showing which subject is less studied in which health institution and unit. Within the scope of this purpose, it is also important to determine the subjects that have not been studied before in order to guide those who will do research in future. In this context, DergiPark database was searched by using the keywords "hospital", "cost", "health facilities" as well as "healthcare enterprises", and bibliometric data were obtained. The studies were examined within the context of "years, health institutions and units analyzed, study subjects, and number of authors". In the study, bibliometric analysis technique which is one of the qualitative research methods was used. A total of 72 articles that were evaluated within the framework of bibliometric characteristics were analyzed. Following the analysis, it was found that the number of articles gained momentum after 2016 in terms of the distribution of the number of articles by years. The cost analysis of the radiology unit was observed to be significantly higher than the other units. As a result, status quo of the health care cost-related articles written in Turkey and published in DergiPark was tried to be uncovered. The information gap in the area was bridged by the bibliometric analysis, and it was concluded that it would guide the studies to be carried out thereafter.
\end{abstract}

Keywords: Health Institutions, Cost in Health Care, Cost Analysis, Bibliometric Analysis 


\section{Giriş}

Sağlık kurumlarında artan teşhis ve tedavi maliyetleri ile artan sağlık hizmeti ihtiyacı, kaynakların daha etkin ve verimli kullanılmasını zorunlu hale getirmiştir. Sağlık hizmetlerinde katlanılan maliyetin analiz edilmesi sağlık kurumlarında hizmet devamlılığı açısından oldukça önemlidir.

Sağlıkta maliyet alanında yapılan akademik çalışmalar, sağlık kurumlarındaki yöneticiler başta olmak üzere kanun yapıcılara ve topluma katkı sağlayıcı niteliktedir. Bu çalışmalar, genel olarak maliyet hesaplama veya maliyetlerin analizi şeklinde olabilirken, özelde bir takım maliyet alt konularının sağlık kurumlarında uygulanması şeklinde de olmaktadır.

Her çalışmada olduğu gibi sağlıkta maliyet çalışma fikrinden yola çıkıldığında literatürde bu konuda yapılan çalışmaları incelemek; farklı bir yön bulmaya çalışmak söz konusu olmaktadır. Araştırmacılara sağlıkta maliyet çalışmalarının bibliyometrik bir analizini sunmak ve çalışılmamış alanları ortaya çıkarmak ana fikrinden yola çıkılan bu çalışmada, sağlık kurumlarında maliyetin öneminden ve bibliyometrik analizden bahsedilerek, sağlıkta maliyet konulu makale çalışmalarının bibliyometrik analizine yer verilmiştir.

\section{Sağlık Kurumlarında Maliyet}

Sağlık sektöründe giderek artan maliyetler, rekabet koşulları, devletin sürekli olarak sağlı harcamalarını kontrol altına alma isteği ve bu yöndeki uygulamaları gibi nedenler sağlık kurumları yöneticilerinin maliyet unsurlarını karar alma aşamasında kullanma ihtiyacını daha da artırmıştır. Sağlık kurumlarında yöneticilerin hem genel planlama hem de bölümlere ilişkin planlama, yürütme ve denetim faaliyetlerini istenilen düzeyde yapabilmesi için, sabit ve değişken maliyetleri bilmeleri gerekmektedir (Kısakürek vd., 2011, s.44). Bunun yansıra tüm sağlık kurumları kâr amacı gütsün veya gütmesin sundukları sağlık hizmetinin kalitesini yükseltip kaynaklarını da verimli kullanmak durumundadırlar. Maliyetleri hesaplamak ve düşürmek bu noktada tüm işletmeler gibi sağlık kurumlarında da önem kazanmaktadır (Aslantaş Ateş vd., 2018, s.88). İsrafların önlenmesi için maliyet kalemlerinin sistematik olarak kontrol edilmesi, bu hususta hayati değer taşımaktadır.

Sağlık kurumları, teknoloji yoğun ve sabit giderleri fazla olan işletmelerdir. Bu sebeple birim muayene hizmet maliyetlerini azaltabilmek için işlem süreçlerinin hızlandırılarak daha fazla hastanın muayene edilmesi birim muayene maliyetlerini azaltıcı etki yapabilmektedir (Çam ve Karaisaoğlu, 2008, s.23). Üretilen sağlık hizmeti için katlanılan maliyetlerin etkililiği de değerlendirilmelidir. Hizmet maliyetinin tam olarak saptanabilmesi maliyet kontrolü, maliyet denetimi ve kaynakların etkin dağılımının sağlanması adına önemli rol oynamaktadır Sağlık kurumlarında maliyet unsurları, direkt personel, tıbbı sarf malzeme, genel sarf malzeme, ilaç giderleri, endirekt personel, ısınma, yolluklar, endirekt üretim giderleri ve dış kaynak kullanımı olarak sayılabilir. Bu maliyet unsurlarının maliyetler içerisindeki etkilerinin doğru olarak hesaplanabilmesi için sağlıklı sonuçlar veren maliyet sistemleri kullanılmalıdır.

\section{Bibliyometrik Analiz}

Diodato, bibliyometri kavramını matematiksel ve istatistiksel tekniklerle, yayımlanmış dergi, kitap, vb. bilimsel bilgi paylaşım araçlarının incelenmesinde kullanılan yöntem olarak tanımlamıştır (Diodato, 1994, akt. Çicek ve Kozak 2012, s.736). Bibliyometrik araştırmalarda belgelerin ya da yayınların belirli özellikleri analiz edilerek bilimsel iletişime ilişkin çeşitli bulgular elde edilmektedir (Al ve Çoştur, 2007, s.144). Bibliyometrik bulgular disiplinlere göre farklılıkların ortaya çıkarılmasını ya da herhangi bir derginin daha yakından tanınmasını sağlayabilmektedir (Yalçın 2010, s.211). Bibliyometrik analiz sayesinde bilimsel yayınlar da bir çok gösterge ile değerlendirmeye alınmaktadır. 
Liteatürdeki bibliyometrik analiz çalışmalarının çoğunun akademik dergilere ilişkin alan yayınlarının bibliyometrik özellikler kapsamında gerçekleștirildiği görülmektedir (Ryan,2005; Hotamışl1, Erem, 2014; Yalçın, 2010; Polat ve Ark, 2013; Kozak, 2003; Al ve Çoştur, 2007; Kalyane ve Sen, 1995; Ulu ve Akdağ, 2015). Bozdemir ve Taşlı (2018), hastalık maliyetini analizini bibliyometrik açıdan incelemiş ve hastalık maliyeti alanında çalışma yapmak isteyen araştırmacılara konu hakkında en hızlı şekilde ilerleyebilmek adına en çok atıf alan ilk on çalışmayı sunmuştur.

Sağlıkta maliyet alanında bilimsel yayınlanan sağlık maliyet çalışmalarını hangi konuları kapsadığı, ne tür sağlık kuruluşlarında gerçekleştirildiği, yayınların yıllar arası dağılımı ve yazar sayısı gibi faktörler açısından incelenmesi ihtiyacı duyulmuştur. Sağlık hizmetlerinde maliyet konularında yapılan çalışmaların incelenen konuların neler olduğunu ortaya koyarak yıllar bazında nasıl değişim gösterdiğinin karşılaştırmalı olarak değerlendirmesi daha iyi anlaşılmasını sağlayabilecektir. Bahsi geçen durumu gözler önüne serebilmek adına bibliyometrik analiz tercih edilmiştir.

\section{Araştırmanın Amacı}

$\mathrm{Bu}$ araştırmanın amacı;

a) Sağlık alanında maliyet çalışılan makaleleri,

b) Maliyetin en çok hangi yönünün çalışıldığını,

c) En fazla hangi sağlık kurumunun ve biriminin uygulamaya konu edildiğini,

tespit etmek ve böylece hangi sağlık biriminde hangi konunun daha az çalışıldığını göstererek araştırmacılara yol göstermektir. Bu noktada çalışmanın önemi de ortaya çıkmaktadır.

\section{Araştırmanın Kapsamı, Yöntemi ve Sınırlılıkları}

Yukarıda belirtilen amaçlar doğrultusunda bu araştırma Dergipark' da yapılmıştır. DergiPark, Türkiye'de akademik bilgi erişiminde en çok kullanılan araştırma alanı olması sebebiyle sağlık maliyeti adına yayınlanan makalelerin bibliyometrik analizi için veri kaynağı olarak seçilmiştir. DergiPark dışındaki online dergilerdeki kongre bildiri çalışmaları, yayımlanan yüksek lisans ve doktora tezleri kapsam dışında bırakılmıştır.

Çalışma kapsamındaki yayımlanmış tüm makalelere ilişkin bilgiler Excel programına aktarılmış, tüm hesaplamalar, tablolar ve grafikler bu program üzerinden gerçekleştirilmiştir. Çalışmanın planlama aşamasında, çalışmanın başarılı olması ve daha ayrıntılı verilere ulaşılması amacıyla Dergipark' da "hastane", "maliyet", "sağlık kurumları" ve "sağlık işletmeleri” anahtar kelimeleri kullanılarak tarama yapılmıştır. Taramada "hastane" anahtar kelimesinden 1896, "maliyet" anahtar kelimesinden 2280, "sağlik kurumları" anahtar kelimesinden 144 ve "sağlık işletmeleri" anahtar kelimesinden 48 adet makaleye rastlanılmıştır. Toplamda elde edilen 4368 adet makalenin 4250 kadarı konuyla ilgili olmaması başka bir ifadeyle herhangi bir sağlık biriminde maliyet çalışmamış olması sebebiyle ilk etapta elenmiştir. Geriye kalan 118 adet çalışma kaydedilmiştir. Kaydedilen makaleler incelendiğinde bir kısmının birbiriyle aynı olduğu; bir kısmının ise araştırma konusunu tam anlamıyla karşılamadığı; bir kısmının anahtar kelime bölümünde maliyetle ilgili bir kelime bulunmadığı tespit edilmiş ve bunlar da elenmiştir. Nihayetinde 72 makale çalışma kapsamına alınmış ve incelenmiştir. Aşağıdaki şemada bu durum özetlenmiştir. 


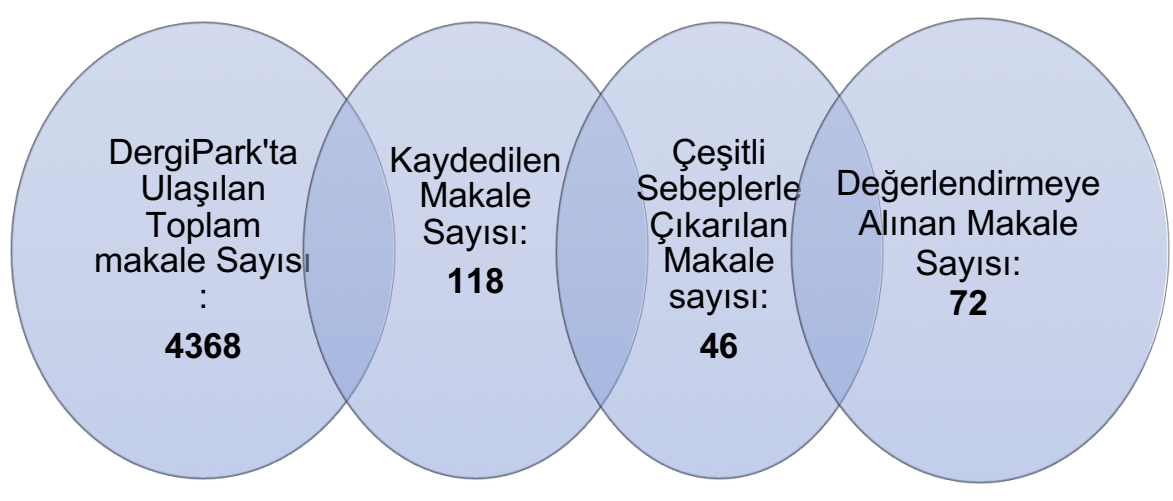

Şekil 1. Makalelerin süreci

Araştırma için herhangi bir yıl sınırlaması yapılmamıştır. Yalnızca 2019, araştırmanın yapıldığı anda devam eden yıl olduğundan elenmiş; bunun dışında kalan ve Dergipark' da tarama sonucunda mevcut tüm yıllar çalışmaya dahil edilmiştir.

$\mathrm{Bu}$ çalışmada veri analizi için bibliyometrik analiz kullanılmıştır. Bir bilim alanında yayımlanmış çalışmalar, farklı bibliyometrik özellikler açısından incelenerek, elde edilen bulgularla literatüre katkı sağlanmaktadır. Bibliyometrik analiz çalışmaları sayesinde incelenen yayınların ya da belgelerin belirli özellikleri bakımından değerlendirilmesi söz konusudur. Bibliyometrik analiz, belirli bir alanda belirli bir dönemde ve belirli bir bölgede kişiler ya da kurumlar tarafından üretilmiş yayınların ve bu yayınlar arasındaki ilişkilerin sayısal olarak analizidir (www.cabim.ulakbim.gov.tr). Herhangi bir bilim dalıyla ilgili üretilmiş her türden yazılı literatürün belli dönemlerde incelenmesi, o bilim dalındaki gelişmelerin ortaya konulması bakımından önemlidir (Kozak, 2000, s.16). Bibliyometrik analizle elde edilen bulgular, bilim dallarındaki ilerlemeler ve geçirmiş oldukları evreler hakkında bilgi vermekle beraber, geleceğe yönelik de değerlendirmeler yapılmasına olanak tanımaktadır (Şakar ve Cerit, 2013, s.38).

Bu doğrultuda çalışma kapsamına alınan makaleler, yayımlandıkları yıllar, yazar sayıları ve anahtar kelimeler bağlamında analize tabi tutulmuştur. Çalışmanın bel kemiğini oluşturan anahtar kelimeler öncelikle gruplanmıştır. Genel olarak maliyet, maliyet analizi, maliyet hacim kâr analizi anahtar kelimelerini içeren makalelerin anahtar kelimesi "maliyet analizi" olarak kabul edilmiştir. Maliyetin alt konuları ise bu gruba ve de herhangi bir gruba dahil edilmeyerek ayrı ayrı listeye eklenmiştir. Yine sağlı birimlerinde birim maliyet hesaplama ve ilaç/hasta maliyeti hesaplama da birer anahtar kelime olarak tabloda yer almaktadır.

$\mathrm{Bu}$ şekilde oluşturulan listeye, çalışmalarda kullanılan anahtar kelimeler sayılarak değerler girilmiştir. Böylece ilk olarak hangi anahtar kelimenin kaç çalışmada yer aldığı ortaya konmuştur. Anahtar kelimelerin tasnifinde ikinci olarak sağlık birimleri tablosu oluşturulmuştur. Bu tabloda hangi sağlık alanında hangi anahtar kelimenin kaç kez kullanıldığının tespiti yer almaktadır. Sağlık kurumları ve sağlık kurumları içinde yer alan birimlerin, kavramsal çalışmaların, hemşirelik hizmetlerinin, evde bakım hizmetlerinin sıralandığı bu tabloda genel olarak çalışmalarda yer alan anahtar kelimelerle sağlık birimleri eşleştirilmiştir. Son olarak da buradan sağlık kurumları ve sağlık birimlerine ait kısımlar çekilerek iki ayrı tabloda gösterilmiştir.

\section{Bulgular}

\section{Yıllara Göre Makaleler}

Çalışma kapsamına alınan 2004-2018 yılları arasındaki makalelerin yıl bazındaki dağılımları Grafik 1'de gösterilmiştir. Aşağıda yer alan Grafik 1' de görüldüğü üzere, 2006 ve 2009 yıllarında sağlık alanında maliyet konulu makale yazılmamıştır. 2018 yllında ise 20 makale ile incelenen dönem itibariyle en yüksek seviyeye 
ulaşılmıştır. 2017 yılındaki 13 makale ile birlikte değerlendirildiğinde, bu alandaki farkındalık son yıllarda artmıştır denebilir. Bu açıdan bakıldığında 2019 yılında bu konuda daha fazla makale yazılacağı beklentisi doğmaktadır.

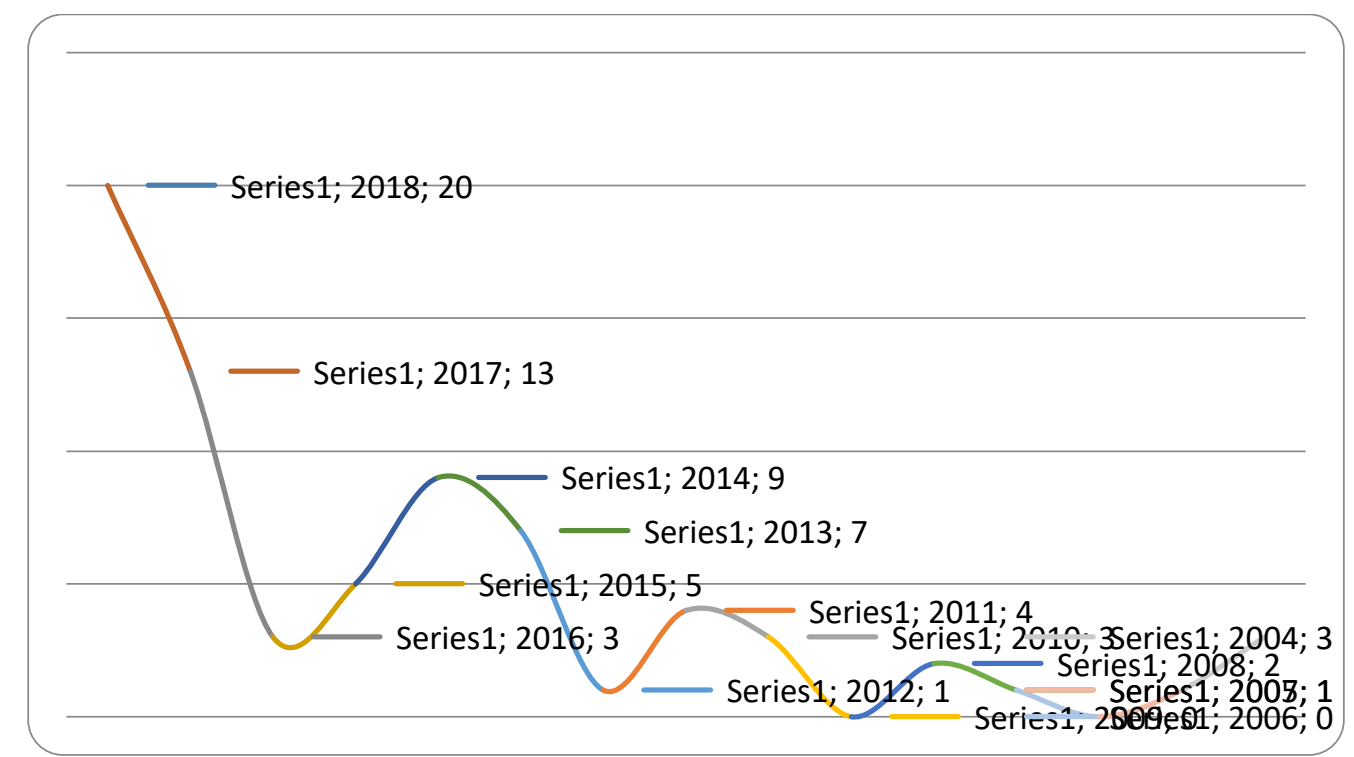

Grafik 1. Makalelerin yıllar itibariyle dağılımı

\section{Yazar Sayılarına Göre Makaleler}

Aşağıdaki grafikte makalelerin kaç yazarlı olarak yazıldığı görülmektedir. Yapılan çalışmalarda yazar sayısı göre dağılım pasta grafiği ile çizilmiş ve 7 paydan oluşmuştur.

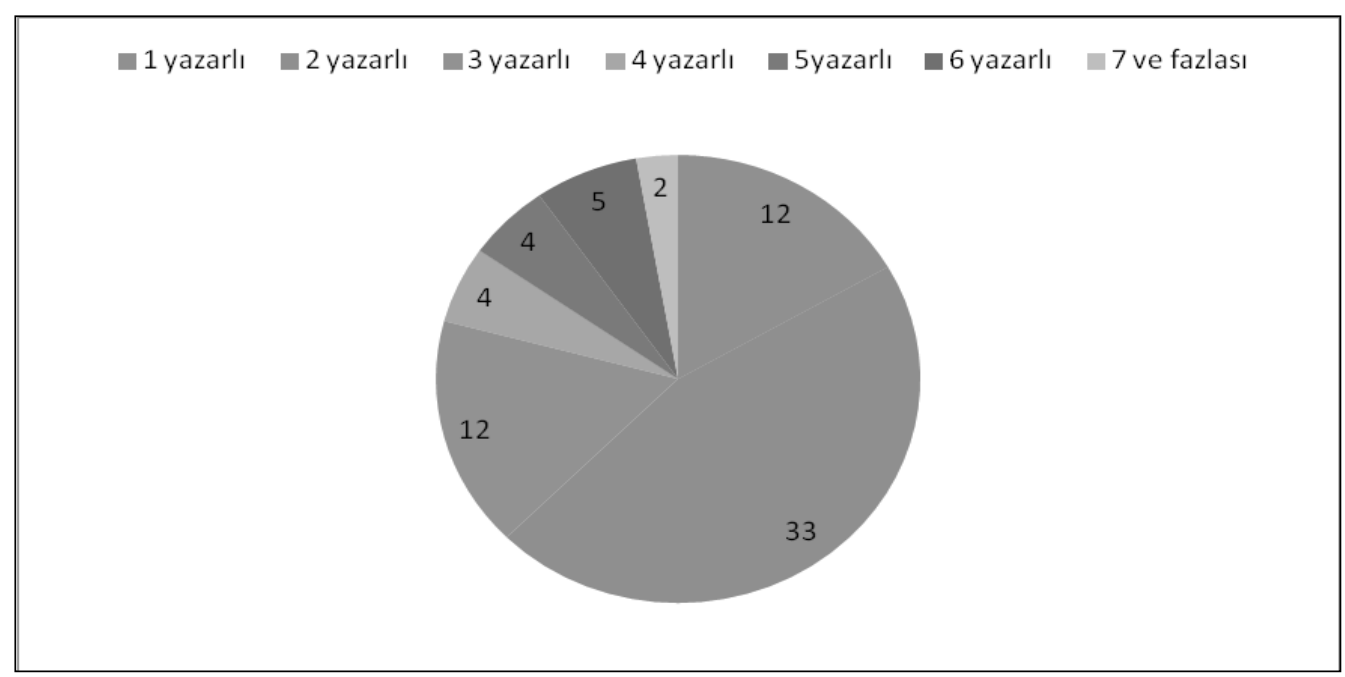

Grafik 2. Makalelerin yazar sayısı itibariyle dağılımları

Grafik 2' den görüldüğü üzere makalelerin 33 adedi 2 yazarlıdır. Sonrasında 12 makale ile 1 ve 3 yazarlı olanlar gelmektedir 4 ve 5 yazarın yer aldığı makale sayıları da birbirine eşit biçimde dörder adettir. 6 yazarlı makale sayısı 2 adet iken, 7 den fazla sayıda yazarın birleşerek yazdığı makale 2 adettir. 7 ve fazlası şeklinde adlandırılan bu gruptaki 2 makalenin yazar sayısı da 13 kişidir. Bu kişi sayısı sosyal bilimler için çok fazla görülmesine karşın Tıp alanında normal karşılanmaktadır. Nitekim bu iki makale de doktorlar tarafından yapılmıştır. 


\section{Anahtar Kelimelere Göre Makaleler}

Çalışmanın amacı daha öncede belirtildiği gibi sağlık alanında yapılan "maliyet" çalışmalarının bibliyometrik analizini yapmaktır. Bu amaç doğrultusunda en önemli bulgu incelenen çalışmalarda kullanılan anahtar kelimelerdir. Anahtar kelimeler çalışmanın hangi alanla ilgili olduğunu göstermek noktasında okuyucuya hem genelde hem de özelde bakış açısı sunmaktadır. Anahtar kelimeler aynı zamanda çalışılan konuyu ifade ettiğinden bu çalışmada "anahtar kelime" ve "çalışılan konu" birbiri yerine kullanılabilmektedir. Analize dahil edilen 72 makalenin hangi maliyet alanında olduğunu incelemek için anahtar kelimeler ve kaç çalışmada kullanıldıkları aşağıda verilen tabloda yer almaktadır.

Tablo 1

Anahtar Kelimelerin Yayınlarda Kullanılma Sıklığı

\begin{tabular}{|l|c|}
\hline ANAHTAR KELIMELER & SIKLIK \\
\hline Maliyet Analizi & 37 \\
\hline İlaç Maliyeti / Hastalık Maliyeti & 15 \\
\hline Faaliyet Tabanlı Maliyetleme & 6 \\
\hline Birim Maliyet & 5 \\
\hline Değer Analizi & 4 \\
\hline Kalite Maliyeti & 3 \\
\hline Hedef Maliyet & 1 \\
\hline Sorumluluk Muhasebesi & 1 \\
\hline $\begin{array}{l}\text { Toplam } \\
\text { 72 }\end{array}$ \\
\hline
\end{tabular}

Tablo 1 hazırlanırken, çalışmalar anahtar kelimeleri itibariyle ele alınmıştır. Esasında bu tablo, makaleler bu çalışma için seçilirken esas alınan kriteri de yansıtmaktadır. Çalışmaların çoğu elbette ki "maliyet" kelimesini anahtar kelime olarak içermektedir. Ancak, anahtar kelimelere göre liste yapılıp yukarıdaki tablo oluşturulurken, genel olarak maliyet ve maliyet analizi çalışılanlar ile anahtar kelimeler kısmında özel bir maliyet alanını içerenler birbirinden ayrıştırılmıştır.

Tablo 1' den görüleceği üzere 72 makalenin 37 sinde "maliyet analizi" anahtar kelimesi yer almaktadır. İlaç ve hastalık maliyeti anahtar kelimeleri ise 15 makalede görülmektedir. Birim maliyet hesaplanan makale sayısı 5 adettir. Genel olarak maliyet çalışılmayıp özelde çeşitli maliyet konularının çalışıldığı makaleler de mevcuttur. Bunların 6 adedinde faaliyet tabanlı maliyetleme, 4 adedinde değer analizi, 3 adedinde kalite maliyeti çalışılmıştır. Hedef maliyet ve sorumluluk muhasebesi ise birer kez çalışılmıştır.

\section{Anahtar Kelimelerin Dağılımı}

Bu kısımda öncelikle tüm çalışmaları içeren bir tablo yer almaktadır. Tabloda, incelenen makalelerde hangi sağlık biriminde hangi konunun kaç kez yer aldığ̣ görülmektedir. 
Tablo 2

Anahtar Kelimelerin Dağılımı

\begin{tabular}{|c|c|c|c|c|c|c|c|c|c|c|}
\hline Sira & Hastane/Bölüm & $\begin{array}{l}\text { Maliyet } \\
\text { Analizi }\end{array}$ & $\begin{array}{l}\text { Birim } \\
\text { Maliyet }\end{array}$ & $\begin{array}{l}\text { İlaç/ } \\
\text { Hastalık } \\
\text { Maliyeti }\end{array}$ & $\begin{array}{l}\text { Değer } \\
\text { Analizi }\end{array}$ & $\begin{array}{l}\text { Faaliyet } \\
\text { Tabanlı } \\
\text { Maliyetleme }\end{array}$ & $\begin{array}{l}\text { Kalite } \\
\text { Maliyeti }\end{array}$ & $\begin{array}{l}\text { Hedef } \\
\text { Maliyet }\end{array}$ & $\begin{array}{l}\text { Sorumluluk } \\
\text { Muhasebesi }\end{array}$ & TOPLAM \\
\hline 1 & Acil Servis & & & 4 & & & & & & 4 \\
\hline 2 & Anestezi & 1 & & 1 & & & & & & 2 \\
\hline 3 & Anjio Ünitesi & 2 & & & & & & & & 2 \\
\hline 4 & Biyomedikal Birimi & 1 & & & & & & & & 1 \\
\hline 5 & Çocuk Acil Servisi & & & 1 & & & & & & 1 \\
\hline 6 & Çocuk Cerrahisi & 1 & & & & & & & & 1 \\
\hline 7 & Çocuk Hastalıkları & 1 & & & & & & & & 1 \\
\hline 8 & Dahiliye & & & 1 & 1 & & & & & 2 \\
\hline 9 & Diyaliz & & & & & & & 1 & & 1 \\
\hline 10 & Erişkin Yoğun Bakım & 1 & & 1 & & & & & & 2 \\
\hline 11 & Fizik Tedavi Rehabilitasyon & 1 & 1 & & & & & & & 2 \\
\hline 12 & Genel Cerrahi & 1 & & & & 1 & & & & 2 \\
\hline 13 & 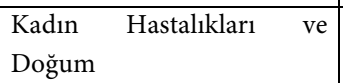 & & & 2 & & & & & & 2 \\
\hline 14 & Kalp Damar Cerrahisi & 1 & 1 & & & 1 & & & & 3 \\
\hline 15 & Koroner Yoğun Bakım & & & & 1 & & & & & 1 \\
\hline 16 & Kulak Burun Boğaz & 1 & & & & & & & & 1 \\
\hline 17 & Ortopedi & 1 & & 1 & & & & & & 2 \\
\hline 18 & Radyoloji Birimleri & 9 & 1 & & 1 & 2 & & & & 13 \\
\hline 19 & Tüp Bebek Ünitesi & & 1 & & & & & & & 1 \\
\hline 20 & Üroloji & 1 & & & & & & & & 1 \\
\hline 21 & Yenidoğan Yoğun Bakım & & 1 & & & & & & & 1 \\
\hline & & & & & & & & & & \\
\hline 22 & Evde Bakım Hizmeti & 1 & & & & & & & & 1 \\
\hline 23 & Hemşirelik Hizmetleri & 1 & & & & & & & & 1 \\
\hline & . & & & & & & & & & \\
\hline 24 & $\begin{array}{l}\text { Birinci Basamak Resmi } \\
\text { Sağllk Kuruluşu }\end{array}$ & 1 & & & & & & & & 1 \\
\hline 25 & $\begin{array}{l}\text { İkinci Basamak } \\
\text { Resmi Sağlık Kurumu }\end{array}$ & 3 & & & 1 & & 2 & & 1 & 7 \\
\hline 26 & $\begin{array}{l}\text { İkinci Basamak Resmi } \\
\text { Sağlık Kurumu }\end{array}$ & & & & & 2 & & & & 2 \\
\hline 27 & $\begin{array}{l}\text { İkinci Basamak Resmi } \\
\text { Sağlık Kurumu }\end{array}$ & 1 & & 1 & & & & & & 2 \\
\hline 28 & $\begin{array}{l}\text { İkinci Basamak Özel } \\
\text { Sağlık Kuruluşu }\end{array}$ & 1 & & & & & & & & 1 \\
\hline 29 & $\begin{array}{l}\text { Üçüncü Basamak } \\
\text { Sağlık Kurumu }\end{array}$ & 1 & & 1 & & & 1 & & & 3 \\
\hline & & & & & & & & & & \\
\hline 30 & Kavramsal Çerçeve & 6 & & 2 & & & & & & 8 \\
\hline & Toplam & 37 & 5 & 15 & 4 & 6 & 3 & 1 & 1 & 72 \\
\hline
\end{tabular}

Tablo 2' de 1-21 sıra sayılı kısım, bir sağlık kuruluşu içerisindeki birimleri alfabetik sıra ile göstermektedir. Bu grup içerisinde ayaktan ya da yatarak tedavi hizmeti sunan bölümler mevcuttur. Yanı sıra tetkike yardımcı birimler de vardır. 
22 ve 23 sıra sayıları ise evde bakım hizmeti ve hemşirelik hizmetlerini içermektedir. Her ikisi de sağlık kuruluşu içerisinde yer almayan bir alanda yapılan çalışma olduğu için tabloda ayrı tutulmuştur. İkisinden de birer adet mevcuttur ve her ikisi de "maliyet analizi" konusundadır.

24-29 sıra sayıları arasında olan kısım ise, genel olarak sağlık kuruluşunun tamamının ele alındığı; herhangi bir muayene, tedavi, tetkik birimi özeline inilmediği çalışmaları içermektedir. Bu grup da kendi içerisinde Sağlık Bakanlı̆̆ı’ nın genelgelerinde belirtilen sağlık kurumları listesine göre sıralanmıştır.

Son sırada yer alan ve "kavramsal çerçeve" şeklinde belirtilen çalışma grubu ise herhangi bir sağlık kurumu ya da sağlık kurumu içerisinde bir birimde uygulama yapılmayan; konunun kavramsal olarak ele alındığı çalışmaları kapsamaktadır. Bunlardan 6 adedi "maliyet analizi", 2 adedi ise "ilaç/hastalık maliyeti" konusundadır. $\mathrm{Bu}$ tablodaki sağlık kurumları ve sağlı kurumları içindeki birimler aşağıda iki ayrı tabloda ayrıntılı olarak incelenmektedir.

Tablo 3

Sağlık Kurumlarına Göre Anahtar Kelimeler

\begin{tabular}{|l|c|l|l|l|l|c|c|}
\hline Sağlık Kurumu & $\begin{array}{l}\text { Maliyet } \\
\text { Analizi }\end{array}$ & $\begin{array}{l}\text { İlaç/ } \\
\text { Hastalık } \\
\text { Maliyeti }\end{array}$ & $\begin{array}{l}\text { Değer } \\
\text { Analizi }\end{array}$ & $\begin{array}{l}\text { Faaliyet } \\
\text { Tabanlı } \\
\text { Maliyetleme }\end{array}$ & $\begin{array}{l}\text { Kalite } \\
\text { Maliyeti }\end{array}$ & $\begin{array}{l}\text { Sorumluluk } \\
\text { Muhasebesi }\end{array}$ & TOPLAM \\
\hline $\begin{array}{l}\text { İkinci Basamak Resmi Sağlık Kurumu } \\
\text { (Devlet/Şehir Hastaneleri) }\end{array}$ & 3 & & 1 & & 2 & 1 \\
\hline $\begin{array}{l}\text { Üçüncü Basamak Sağlık Kurumu } \\
\text { (Eğitim-Araştırma Hastaneleri/ } \\
\text { Üniversite Hastaneleri) }\end{array}$ & 1 & 1 & & & & $\mathbf{3}$ \\
\hline $\begin{array}{l}\text { İkinci Basamak Resmi Sağlık Kurumu } \\
\text { (Ağı DişSağlığı Merkezleri) }\end{array}$ & & & & 2 & & & $\mathbf{2}$ \\
\hline $\begin{array}{l}\text { İkinci Basamak Resmi Sağlık Kurumu } \\
\text { (Doğum ve Çocuk Hastaneleri) }\end{array}$ & 1 & 1 & & & & $\mathbf{2}$ \\
\hline $\begin{array}{l}\text { İkinci Basamak Özel Sağlık Kuruluşu } \\
\text { (Özel Hastaneler) }\end{array}$ & 1 & & & & & $\mathbf{1}$ \\
\hline $\begin{array}{l}\text { Birinci Basamak Resmi Sağlık Kuruluşu } \\
\text { (Sağlı Ocakları/Aile Hekimlikleri) }\end{array}$ & 1 & & & & & & $\mathbf{1}$ \\
\hline
\end{tabular}

Sağlık kurumlarında çalışılan maliyet konuları tablo 3' de görülmektedir. Daha önce de bahsedildiği üzere Sağlık Bakanlığı tebliğlerine göre sağlık kurumları birinci, ikinci, üçüncü basamak olarak gruplandırılmıştır. Yukarıdaki tabloda da bu gruplandırma esas alınmış ve en çok çalışma yapılan kuruluştan en aza doğru sıralanmıştır. Buna göre ikinci basamak resmi sağlik kurumu olarak nitelenen devlet/şehir hastanelerinde 7 çalışma; üçüncü basamak sağlık kurumu olarak nitelenen eğitim araştırma/ üniversite hastanelerinde 3 çalışma yapılmıştır. Yine ikinci basamak resmi sağlık kurumuna giren ağız diş sağlığı merkezleri ile doğum ve çocuk hastanelerinde ikişer çalışma mevcuttur. İkinci basamak özel sağlık kuruluşu içinde yer alan özel hastaneler ve birinci basamak olarak ifade edilen sağlık ocakları/aile hekimlikleri kategorilerinde ise birer çalışma yapıldığı görülmektedir.

Maliyet analizi konusu ağız diş sağlığı merkezleri hariç diğer tüm kuruluşlarda çalışılmıştır. Tabloda belirtilen diğer alt maliyet alanlarından ilaç/hastalık maliyeti eğitim araştırma/üniversite hastaneleri ile doğum ve çocuk hastanelerinde birer kez çalışılmıştır. Kalite maliyetleri konusu 2 kez devlet/şehir hastanelerinde, 1 kez de eğitim araştırma/üniversite hastanelerinde çalışılmıştır. Faaliyet tabanlı maliyetleme ağız ve diş sağlığ 1 merkezinde $2 \mathrm{kez}$ araştırmaya konu edilmiştir. Yine devlet/şehir hastaneleri kategorisinde değer analizi ve sorumluluk muhasebesi konuları birer kez çalışılmıştır. 
Tablo 4, bir sağlık kurumu içerisinde yer alan poliklinik, yataklı birimler ve tetkik ünitelerinde hangi maliyet konusunun ne sıklıkta çalışılmış olduğunu göstermektedir.

Tablo 4

Sağlık Birimlerine Göre Anahtar Kelimeler

\begin{tabular}{|c|c|c|c|c|c|c|c|c|}
\hline Sira & Hastane/Bölüm & $\begin{array}{l}\text { Maliyet } \\
\text { Analizi }\end{array}$ & $\begin{array}{l}\text { Birim } \\
\text { Maliyet }\end{array}$ & $\begin{array}{l}\text { İlaç/ } \\
\text { Hastalık } \\
\text { Maliyeti }\end{array}$ & $\begin{array}{l}\text { Değer } \\
\text { Analizi }\end{array}$ & $\begin{array}{l}\text { Faaliyet } \\
\text { Tabanlı } \\
\text { Maliyetleme }\end{array}$ & $\begin{array}{l}\text { Hedef } \\
\text { Maliyet }\end{array}$ & TOPLAM \\
\hline 1 & Radyoloji Birimleri & 9 & 1 & & 1 & 2 & & 13 \\
\hline 2 & Acil Servis & & & 4 & & & & 4 \\
\hline 3 & Kalp Damar Cerrahisi & 1 & 1 & & & 1 & & 3 \\
\hline 4 & Anestezi & 1 & & 1 & & & & 2 \\
\hline 5 & Anjio Ünitesi & 2 & & & & & & 2 \\
\hline 6 & Dahiliye & & & 1 & 1 & & & 2 \\
\hline 7 & Erişkin Yoğun Bakım & 1 & & 1 & & & & 2 \\
\hline 8 & $\begin{array}{l}\text { Fizik Tedavi } \\
\text { Rehabilitasyon }\end{array}$ & 1 & 1 & & & & & 2 \\
\hline 9 & Genel Cerrahi & 1 & & & & 1 & & 2 \\
\hline 10 & $\begin{array}{l}\text { Kadın Hastalıkları ve } \\
\text { Doğum }\end{array}$ & & & 2 & & & & 2 \\
\hline 11 & Ortopedi & 1 & & 1 & & & & 2 \\
\hline 12 & Biyomedikal Birimi & 1 & & & & & & 1 \\
\hline 13 & Çocuk Acil Servisi & & & 1 & & & & 1 \\
\hline 14 & Çocuk Cerrahisi & 1 & & & & & & 1 \\
\hline 15 & Çocuk Hastalıkları & 1 & & & & & & 1 \\
\hline 16 & Diyaliz & & & & & & 1 & 1 \\
\hline 17 & Koroner Yoğun Bakım & & & & 1 & & & 1 \\
\hline 18 & Kulak Burun Boğaz & 1 & & & & & & 1 \\
\hline 19 & Tüp Bebek & & 1 & & & & & 1 \\
\hline 20 & Üroloji & 1 & & & & & & 1 \\
\hline 21 & Yenidoğan Yoğun Bakım & & 1 & & & & & 1 \\
\hline
\end{tabular}

Yukarıdaki tabloya göre; incelenen dönemdeki makalelere en çok konu edilen sağlık birimi MR Ünitesi, tomografi gibi radyoloji birimleridir. Bu birimde toplam 13 çalışma yapılmıştır ve tabloda görülen diğer birimlerde yapılan çalışmalardan epeyce öndedir. Çalışmaların 9 adedinde genel olarak maliyet analizi yapılmıştır. 2 çalışma faaliyet tabanlı maliyetleme, birer çalışma ise birim maliyet hesaplama ve değer analizi konularındadır.

Acil servis biriminde 4 çalışma mevcut olup hepsi ilaç/hastalık maliyeti konusundadır. Kalp damar cerrahisinde 3 çalışma yapıldığı görülmektedir. Bu çalışmalar, maliyet analizi, birim maliyet ve faaliyet tabanlı maliyetleme konularındadır. 
Anestezi, anjiyo, dahiliye, erişkin yoğun bakım, fizik tedavi rehabilitasyon, genel cerrahi, kadın hastalıkları ve doğum ile ortopedi birimlerinde ikişer çalışma mevcuttur. Çalışmaların geneli maliyet analizi konusundadır. Yalnızca dahiliye ve kadın hastalıkları ve doğum birimlerinde maliyet analizi konusunda çalışma yoktur. Kadın hastalıkları ve doğum biriminde yapılan iki çalışma da ilaç/hastalık maliyeti konusundadır.

Tablodan görüldüğü üzere diğer birimlerde birer çalışma mevcuttur. Tüp bebek merkezi ve yenidoğan yoğun bakımda birim maliyet, çocuk acil serviste ilaç/ hastalık maliyeti, koroner yoğun bakımda değer analizi, diyalizde ise hedef maliyet çalışılmıştır. Diğerleri maliyet analizi konusu çalışılan makalelerdir.

\section{Sonuç}

Sağlık alanında yapılan maliyet konulu makalelerin bibliyometrik olarak analiz edildiği bu çalışmada tespit edilen durumlar aşağıda özetlenmektedir:

- Çalışmaların son yıllarda sayıca artmış olduğu tespit edilmiştir. Dolayısıyla sağlıkta maliyetin öneminin giderek daha çok fark edildiği söylenebilir.

- Sağlıkta maliyet çalışmaları daha çok maliyet analizi konusunda yoğunlaşmaktadır.

- İlaç ve hastalık maliyeti de ikinci sırada çalışılan konudur.

- Maliyetin alt konuları sınırlı olarak çalışılmıştır. Bu çalışma kapsamına alınan makalelerde "değer analizi", "kalite maliyetleri", "faaliyet tabanlı maliyetleme", "sorumluluk muhasebesi" ve "hedef maliyet” konuları sınırlı bir biçimde yer almaktadır. Araştırmacılar tarafından diğer maliyet konuları ya da bu maliyet konularının çalışılmadığı sağlık birimleri bundan sonraki araştırmalarda değerlendirilebilir.

- Sağlık kurumu ya da biriminde, bir hastanın birim maliyetini hesaplama konusunun da incelenen makalelerde çok az sayıda çalışıldığ 1 tespit edilmiştir.

- Genel olarak bir sağlık kurumunda çalışılıp özelde herhangi bir birimin konu edilmediği çalışmalar açısından bakıldığında, en fazla sayıda çalışmanın devlet/şehir hastanelerinde yapıldığı görülmektedir.

- Sağlık birimleri açısından konuya yaklaşıldığında en fazla sayıca çalışmanın radyoloji birimlerinde yapıldığı görülmektedir. Radyoloji biriminde yapılan çalışmaların büyük kısmı maliyet analizi çalışmalarıdır. Birim maliyet hesaplama, değer analizi ve faaliyet tabanlı maliyetleme de çalışılmıştır fakat diğer maliyet konuları radyoloji biriminde henüz uygulanmamıştır.

Bu sonuçlar doğrultusunda, ilaç ve hastalık türlerinin maliyet açısından fark yaratacağı beklenen bazı sağlık birimlerinde çalışmaların yapılması, hastane türü olarak da yapılan az sayıda çalışmanın da özel hastaneler ile sağlık ocakları/aile hekimliklerinde olması nedeniyle bu alanlara kanalize olunabileceği önerilmektedir. Ayrıca yukarıdaki kısımda verilen tablolardan faydalanan araştırmacılar, radyoloji dışında diğer sağlık birimlerinde çok az sayıda çalışmanın yapıldığını görebilecekler ve çalışma yapmak için açık alanları kolaylıkla tespit edebileceklerdir.

\section{Kaynakça}

Al, U. ve Çoştur, R. (2007). Türk Psikoloji Dergisi’nin bibliyometrik profili. Türk Kütüphaneciliği, 21(2), 142163. Retrieved from https://dergipark.org.tr/tr/pub/tk/issue/ 48938/624262

Aslantaş Ateş, B., Toraman, A. ve Karatopuk, D. (2018). Üniversite hastanesindeki tüp bebek ünitesinin maliyet analizi. Pamukkale Üniversitesi Sosyal Bilimler Enstitüsü Dergisi, 31, 87-98. doi: 10.30794/pausbed.414622

Bozdemïr, E, Taşlı, M. (2018). Hastalık maliyet analizinin bibliyometrik ve doküman açısından incelemesi. Konuralp Medical Journal, 10(3), 408-419. doi: 10.18521/ktd.449264 
Çam, F. (2008). Sağlık işletmelerinde maliyet analizi: Karaman devlet hastanesinde birim muayene maliyetlerinin hesaplanması. Niğde Üniversitesi İktisadi ve İdari Bilimler Fakültesi Dergisi, 1(1), 15-24. Erişim adresi: https://dergipark.org.tr/tr/pub/niguiibfd/issue/19742/211307

Çiçek, D, Kozak, N. (2012). Anatolia: Turizm Araştırmaları Dergisi'nde yayımlanan hakem denetimli makalelerin bibliyometrik profili. Türk Kütüphaneciliği, 26(4), 734-756. Erişim adresi: https://dergipark.org.tr/tr/pub/tk/issue/48835/622155

Denktaş Şakar, G, Cerï, A. (2013). Uluslararası alan indekslerinde Türkiye pazarlama yazını: Bibliyometrik analizler ve nitel bir araştırma. Atatürk Üniversitesi İktisadi ve İdari Bilimler Dergisi, 27(4), 37-64. Erişim adresi: https://dergipark.org.tr/tr/pub/atauniiibd/issue/2711/35878

Kalyane, V. L. ve Sen, B. K. (1995). A bibliometric study of the Journal of Oilseeds Research. Annals of Library Science and Documentation, 42(4), 121-141. Erişim adresi: http://eprints.rclis.org/4780/1/K-41.pdf

Kısakürek, M, Kılıç, A. (2011). Cumhuriyet Üniversitesi Hastanesi anjiyo ünitesi maliyet-hacim-kar analizi. Elektronik Sosyal Bilimler Dergisi, 10(37), 42-59. Erişim adresi: https://dergipark.org.tr/tr/pub/esosder/issue/6151/82613

Kozak, N. (2000). Türkiye' de akademik turizm literatürünün gelişim süreci üzerine bir inceleme. DAÜ: Turizm Araştırmaları Dergisi, 1(1), 15-55.

Kozak, N. (2003). Türkiye’ de yayınlanan akademik dergilerin niteliklerindeki zaman içerisindeki değişim nedenleri: Sağlık, sosyal ve teknik bilim alanlarında yayınlanan dergiler üzerine bir inceleme. Bilgi Dünyası, 4(2), 146-174. Erişim adresi: http://eprints.rclis.org/7358/

Polat, C, Sağlam, M, Sarı, T . (2013). Atatürk Üniversitesi İktisadi ve İdari Bilimler Dergisi’nin bibliyometrik analizi. Atatürk Üniversitesi İktisadi ve İdari Bilimler Dergisi, 27(2), 273-288. Erişim adresi: https://dergipark.org.tr/tr/pub/atauniiibd/issue/2709/35891

Ryan, C. (2005). The Ranking and Rating of academics and journals in tourism research. Tourism Management, 26, 657-662. doi:10.1016/j.tourman.2004.05.001

Tübitak Ulakbim Cahit Arf Bilgi Merkezi, www.cabim.ulakbim.gov.tr (Erişim, 1.7.2019)

Ulu, S, Akdağ, M. (2015). Yayınlanan hakem denetimli makalelerin bibliyometrik profili: Selçuk İletişim Dergisi örneği. Selçuk İletişim, 9(1), 5-21. Erişim adresi: https://dergipark.org.tr/tr/pub/josc/issue/19031/201134

Yalçın, H. (2010). Millî Folklor Dergisi'nin bibliyometrik profili (2007-2009). Millî Folklor, 22(85), 205-211. Erişim $\quad$ adresi: https://scholar.google.com/scholar?hl=tr\&as_sdt=0\%2C5\&q=Yalçı\%2C+H.+\%282010\%29.+Millî+Fo lklor+Dergisi'nin+bibliyometrik+profili+\%282007-

2009\%29.++Millî+Folklor\%2C+22\%2885\%29\%2C+205-211.\&btnG= 